\title{
鉱物構造の動的変化過程の観察技術の開発と 鉄鋼関連材料製造プロセスへの展開
}

\section{Development of in situ and dynamic observation of changes in mineralogical structures and their application to steel-relating materials and steel making processes}

\author{
木村 正雄(Masao KIMURA)*,**
}

Keywords: In situ, Synchrotron radiation, Sinter, Catalysis, Corrosion

\section{I. はじめに}

社会基盤材料である鉄鋼関連材料の強度・加工性・耐食 性・機能性など現状の実現レベルを大幅に改善すること は，インフラ整備や建築等様々な側面から社会の基盤持続 のために不可欠である。これらの目標を達成するために は, 新素材の開発など注目度の高い新素材の開発研究に加 えて, 素材製造現場で機能する製造プロセスを最適化して いく必要がある。特に今般, 製造プロセスに必要な資源 (鉄鉱石, 石炭, 添加元素として用いる鉱物資源) およびエ ネルギーが劣質化・枯渴化・高騰という非常に厳しい環境 にあることを鑑みると, 次世代の鉄鋼関連材料の製造プロ セスの再構築は, 限られた天然資源を最大限有効活用し て，社会基盤インフラに必須の鉄鋼材料を供給するという 社会的使命を果たすためのキーポイントであると考えられ る。

鉄鋼関連材料が製造されるプロセス環境は，広い温度域 (約 $-50{ }^{\circ} \mathrm{C} \sim 1500{ }^{\circ} \mathrm{C}$ ) 抢よび各種ガス雾囲気など多岐にわ たる(Fig. 1)。しかし, 原料の鉄鉱石, 石灰石, コークス （石炭を乾留したもの）を $1200{ }^{\circ} \mathrm{C}$ 以上の高温で処理して焼 結鉱を作り，部分的には $1800{ }^{\circ} \mathrm{C}$ 高温になる大型の反応 炉である高炉にてその焼結鉱を還元して溶銑をつくる製銑 プロセスでは，酸化物や石炭が高温で様々な反応(焼結, 乾留, 還元)を経験する。当然, その結晶構造は複雑に変 化するわけであり，その反応を理解し制御するためには結 晶学的な研究アプローチが不可欠になる。溶銑プロセスで は高温・ガス䨌囲気下での加熱により含有する化学成分の 制御を行う。そして, 目的に応じて, 形を作り込みなが
ら，機械的特性を制御していく一所謂加工熱処理を行う。 子供の頃に針金を焼き入れして遊んだ経験のある人は容易 にわかるように，鉄鋼材料の機械的特性を制御する一番有 効な方法が加工熱処理である。同じ成分をもつ鋼を異なる 速度で冷却すると, 構成する相の種類は同じ「Fe(bcc) と 微量の $\mathrm{Fe}_{3} \mathrm{C}\left(\mathrm{DO}_{11}\right.$ 構造 $) 」$ であるが, 両相の結晶粒サイズ や分布が大きく変化し, 強度が倍以上異なる。それゆえ, 鉄鋼 (金属)材料屋での議論の出発点は“組織 (micro structure)' である。（異相から構成されることが多い鉱物と異 なる点もあれば，類似している点もある。）また製品と なった鉄鋼材料が様々な環境で用いられる時の反応一例え ば腐食一を理解するためにも, 反応に伴う構造変化が重要 になる。

このような多様なプロセス環境で実現される素材および 材料の構造変化を正しく理解し制御することが，上記の課 題解決には肝要である。しかし原料となる鉄鉱石はもち万 ん, 高温プロセスや腐食環境で生じる生成物および多様多 種の複雑酸化物の変化等を, 実プロセス環境下で,「その 場 (in situ) and 動的 (dynamic) 観察」する試みは, その方 法や解析の開発の問題により，それほど多くはなかった。 鉄鋼関連材料の製造プロセスを新たな次元に進化させるた めには，鉄鋼製造にかかわる多様かつ複雑な酸化物鉱物の 構造变化を動的に追尾し，その反応メカニズムを理解する ことが不可欠であるという信念のもと, 最先端の放射光技 術を活用して, 反応のキーとなる鉱物の原子構造単位の変 化を「その場 (in situ) and 動的 (dynamic) 観察」する, 才 リジナルな観察法の研究開発に取り組んできた。

これらの手法を用いて得られた材料の鉱物構造の変化に

doi: $10.2465 /$ gkk. 140117

(平成 26 年 1 月 17 日受付, 平成 26 年 1 月 22 日受理，担当編集委員 : 赤坂正秀)

$*$ 新日鐵住金株) 先端技術研究所 解析科学研究部

** 現所属: 高エネルギー加速器研究機構・物質構造科学研究所, $=305-0801$ 茨城県つくば市大穂 1-1

* Advanced Technology Research Laboratories, Nippon Steel and Sumitomo Metal Corp.

** Present address: Photon Factory, Institute of Materials Structure Science, High Energy Accelerator Research Organization (KEK), 1-1 Oho, Tsukuba, Ibaraki 305-0801, JapanＥ-mail: masao.kimura@kek.jp 


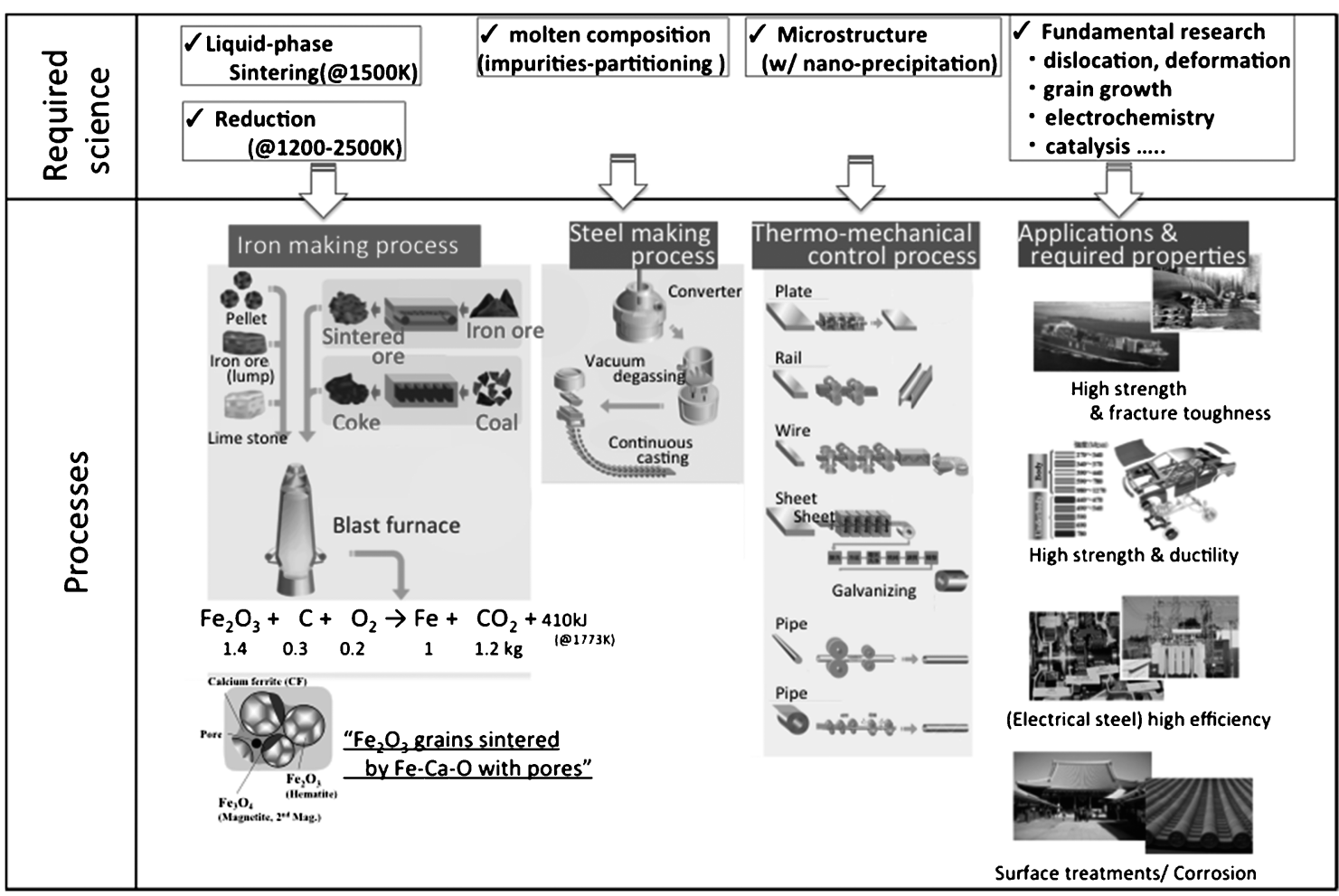

Fig. 1. Illustration of processes for iron and steel making processes (below) and science required for controlling them based on reaction mechanism (above).

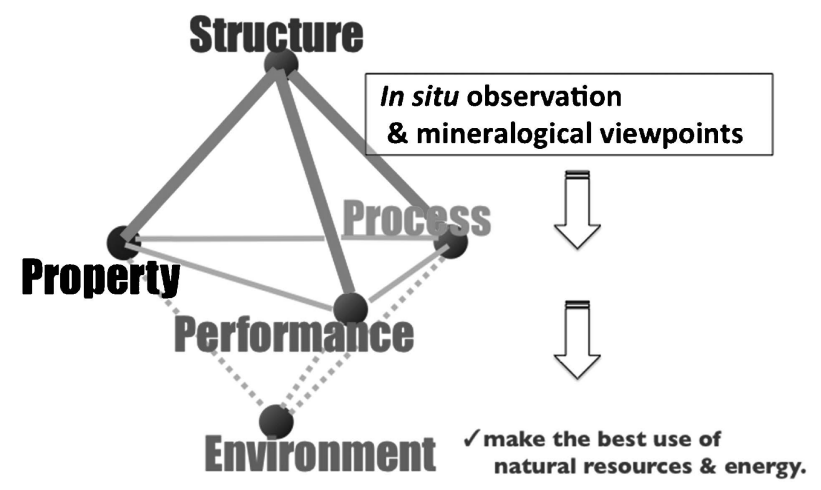

Fig. 2. Illustration of 'materials octahedron' based on processes for iron and steel making processes (below) and science required for controlling them based on reaction mechanism (above).

関する情報は，材料の物性 (property)，実際の供与環境で の発現特性（performance），そして材料の製造行程 (process), の材料の三大要件の機能発現に大きく関与し ている(Fig. 2)。これらを適切に制御することにより，こ れからの材料が求められる第四の要件である環境調和性 (environment ; 省エネルギー, 省資源, Life Cycle Assessment）を最大限高めることができるのである。本稿では代 表的な研究を 2 例取り上げ，そのことを紹介したい。

\section{II. 高温 ( $\left.1500{ }^{\circ} \mathrm{C}\right)$ での $\mathrm{CaO}-\mathrm{Fe}_{2} \mathrm{O}_{3}$ の焼結反応観察}

鉄鋼製造過程において高炉の原料となる焼結鉱は, $\mathrm{Fe}_{2} \mathrm{O}_{3}, \mathrm{CaCO}_{3}$, コークス，等を原料とする焼結プロセス により製造される。この焼結プロセスでは，コークスの燃 焼により原料が $1200{ }^{\circ} \mathrm{C}$ 以上の高温に数分間程度加熱され た後，コークスの燃焼が終了し冷却するまでの短時間( 数分間)に反応が進行する。この過程で進行すると考えら れる主な反応は，

(1) 昇温中に $\mathrm{Fe}_{2} \mathrm{O}_{3}, \mathrm{CaCO}_{3}$, 等の酸化物が相変態およ び相互拡散し $\mathrm{Fe}-\mathrm{Ca}-\mathrm{O}$ 系の複合酸化物 (CF: Calcium Ferrite) が形成，（2）高温で $\mathrm{Fe}-\mathrm{Ca}-\mathrm{O}$ 系の液相および $\mathrm{Fe}_{3} \mathrm{O}_{4}$ が生成，（3）冷却過程で二次へマタイト抢よび CF が再形 成, であり (稲角, 2000), これらの反応が数分間に次々と (マクロ的には)熱力学的非平衡条件下で進行するのが，製 鉄プロセスでの焼結反応である。その結果, 二次へマタイ トおよび原料のへマタイト粒子が CFにより融着した焼結 鉱が形成される。

実際の焼結プロセスは, 約 $1 \mathrm{~m}^{\mathrm{D}} \times$ 数 $\mathrm{m}^{\mathrm{W}} \times 1 \mathrm{~m}^{\mathrm{H}}$ のパ レットと呼ばれる箱 (反応容器) を数 10 個以上並べて移動 させながら連続的に製造され，ひとつの製造ラインで一日 10000 ton 以上の焼結鉱が製造される。用いられる原料で ある鉄鉱石は言うまでもなく鉱山から採取した天然の鉱物 であり，その成分・結晶粒サイズ・脈石成分等もある分布 
をもっている。こうした原料からある一定の幅の特性を もった焼結鉱を，上述したようなスケールで製造してい く。こうした大きなプロセスの中で, 熱力学的非平衡条件 下で進行する焼結反応の詳細なメカニズムを解明し，その 効率を $0.1 \%$ でも向上させることができたら一そのインパ クトは経済的なものたけでなく，天然資源を有効活用する という点で大きいことは容易に理解いただけるであろう。 さらに, 原燃料 (鉄鉱石, 石炭)の質は年々变化 (劣質化)す る傾向にあり，それに対応したプロセスウィンドウの再構 築や新プロセスの開発が求められている。

こうしたことを背景として, 焼結の素反応解析の重要性 は非常に高く，様々な研究アプローチが行われている。そ のひとつとして, 放射光や実験室系 X 線源と二次元検出 器を用いた Quick XRD 法とレーザー顕微鏡を組み合わせ て, $1500{ }^{\circ} \mathrm{C}$ な゙の高温・ガス䨌囲気中で, 結晶構造と組 織の変化を捉える試みを行っている (Kimura and Murao, 2013)。焼結反応では高温での酸化物融体からの酸化物の 析出抽よ゙変態反応が重要となるが，その際，粒成長によ り試料が高い優先配向性を示す事が多い。そのため, Quick XRD 法では, 二次元検出により Debye-Scherrer cone (の一部)を積分する形で測定するため, 従来法の点型 検出器をスキャンさせる方式よりも, 短時間 (1/20以 下), 高 $\mathrm{S} / \mathrm{N}$ 比での測定が可能となった (Fig. 3)。その結 果, (1) Figure 4 に示す様に複雑な構造相変態を示すこ と，（2）昇降温の速度によりその転移温度が熱力学的平衡

(a)
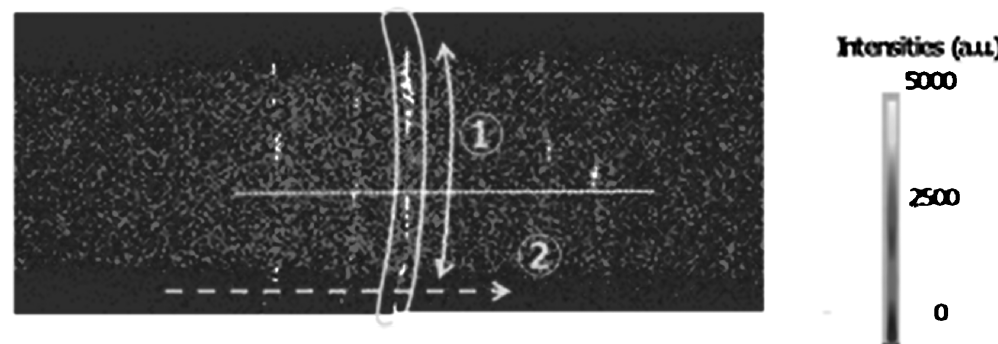

Diffraction angle, $2 \theta$

(b)

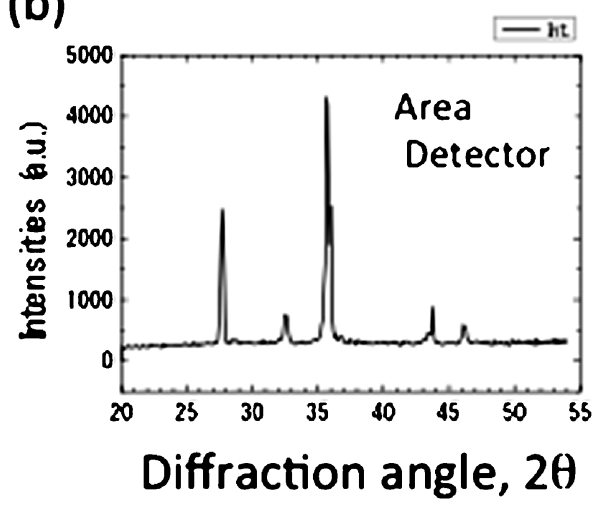

(c)

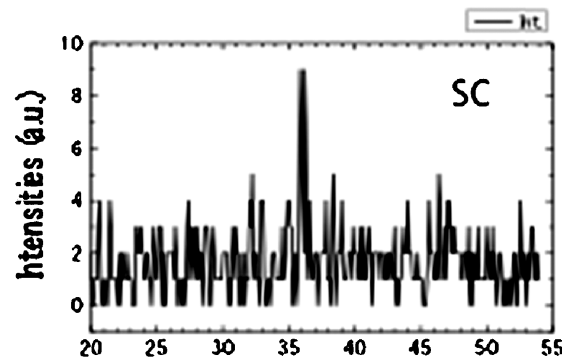

Diffraction angle, $2 \theta$
Fig. 3. (a) $\mathrm{X}$-ray diffraction intensities of the specimen $\mathrm{CaO}: \mathrm{Fe}_{2} \mathrm{O}_{3}=75: 25$ mass $\%$ at $T=1473 \mathrm{~K}$ measured with the area detector. (b) Average intensities along the diffraction angle $(2 \theta)$. (c) Intensities measured with a scintillation detector. 


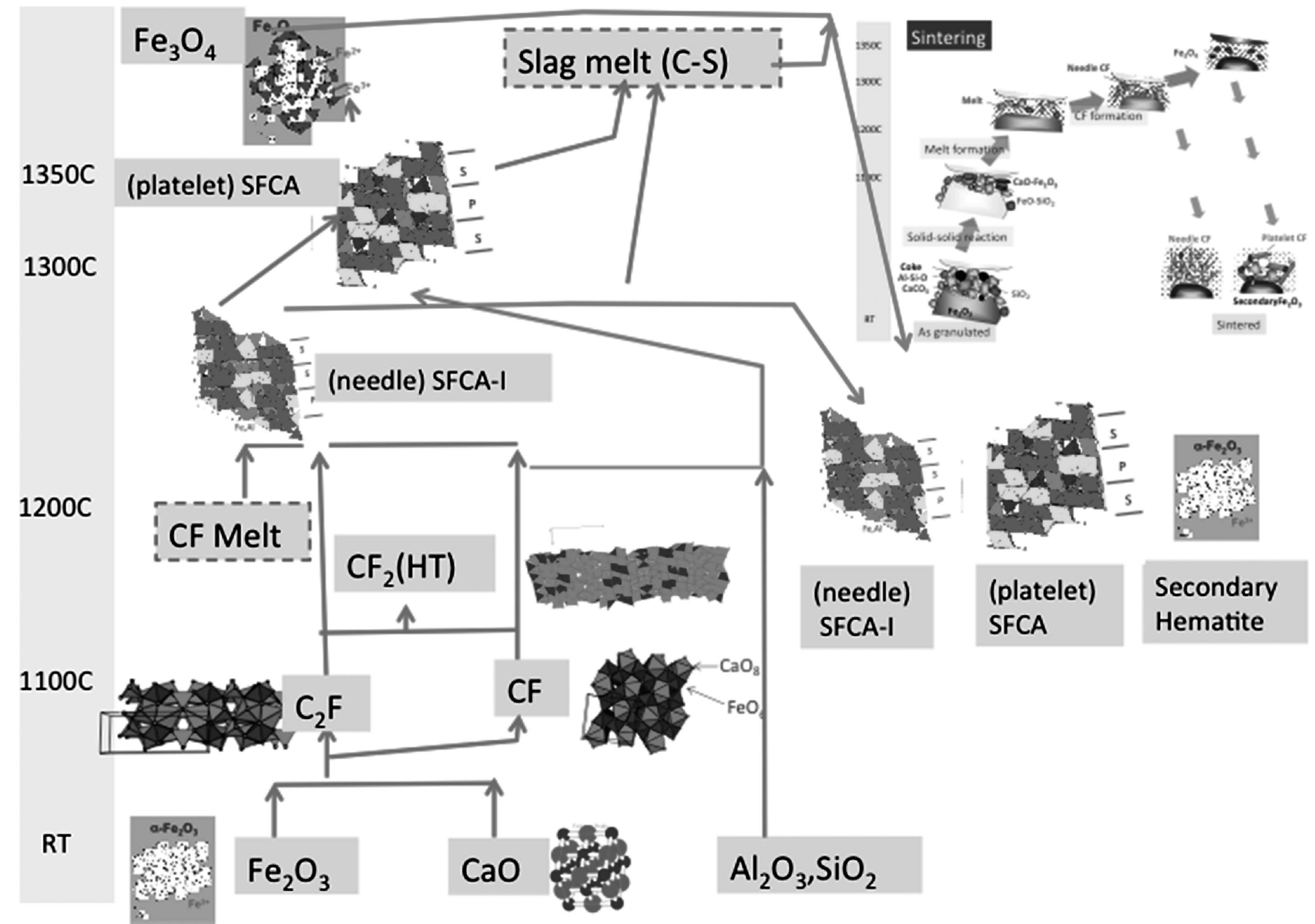

Fig. 4. Illustration of change in crystal structures during the sintering reaction in $\mathrm{CaO}-\mathrm{Fe}_{2} \mathrm{O}_{3}-\mathrm{SiO}_{2}-\mathrm{Al}_{2} \mathrm{O}_{3}$ system.

リア，ピルパラクラトンから，具体的な当時の大陸成長の メカニズムまた太古代表層環境が考察されている（清川, 2000)。それと較べると，数～100 年の時間スケールで 「鉄がさびる」といった現象は極一瞬の出来事かもしれな いが，さびの形成にも，環境の変化が大きく関係してお り，それを調べることよって，“さびでさびを防ぐとい う無塗装で長期大気環境下で使用可能な鋼の開発につな がった例を紹介する。

通常の鋼を大気環境に放置しておくと表面に“さび’が 形成される。鋼表面に形成される“さび’は，鉄のオキシ 水酸化物 $(\alpha-\mathrm{FeOOH}, \cdot \beta-\mathrm{FeOOH}, \cdot \gamma-\mathrm{FeOOH})$ または鉄の 酸化物 $\left(\mathrm{FeO}, \mathrm{Fe}_{3} \mathrm{O}_{4}, \mathrm{Fe}_{2} \mathrm{O}_{3}\right)$ が主な構成相であり,さびの 形成される環境に応じてこれらの相の割合, 構造, 結晶粒 径等が様々に変化する(Misawa et al., 1974; Cornell and Schwertmann，2003）。一般には，「鋼の表面に形成された “さび’はさらなる ‘さび’をよんで腐食が進行する」と 思い込みがちである。しかし，腐食反応の生成物である “さび”を上手に活用すると腐食の進行速度を実用上問題 にならないレベルまで下げることができる。そうした材料 の一つが耐候性鋼 (耐候性＝屋外大気中での耐食性）と呼ば
れる低合金耐食鋼 (Larabee and Coburn, 1962; Matsushima， 1995)で，鋼中への僅かな量の元素添加により耐候性 が向上し, 表面への重塗装なしでも最小限の適切な保守管 理(ミニマムメンテナンス)により 100 年近いレベルの長期 の使用に耐える。近年材料の評価基準として LCA や環境 への負荷低減が重要視されつつあり, 定期的な表層塗装と いった大きな負荷が必要な従来の材料に対して，耐候性鋼 への期待は高まっている。

$\mathrm{n} \mathrm{m}$ 数 $100 \mu \mathrm{m}$ の広いスケールレンジで, 大気腐食に伴 うさびの生成反応を材料構造科学的な視点から解明するた めには, 注目する構造のスケール (三階層)に応じた，構造 観察の手法が必要になる。大気腐食に伴うさびの生成反応 の場合, では，原子が規則正しく配列している距離(原子 相関 : $\lambda$ )の長さに応じて，以下の 3 つの階層での原子相 関が重要になり，それぞれのレベルに敏感な複数の解析手 法を併用して構造解析を実施 [Various Scale Analyses］し た(Kimura et al., 2006)。

(a) $\mathrm{SRO}$ (Short Range Order)

最近接 (NN: Nearest Neighbor) から第三近接 ${ }^{3 \mathrm{rd}} \mathrm{NN}$, $\mathrm{FeOOH}$ の場合で約 $1 \mathrm{~nm}$ 以下の距離) 程度の短距離範囲 $(\lambda$ 
$<1 \mathrm{~nm}$ 程度)でしか，原子相関がみられない原子の配列状 態。所謂, 結晶性の低い状態で, 非晶質 (amorphous) とも 表現される。必ずしも, 非晶質(amorphous)=原子配列に 規則性が全く無い，というわけでないので注意。XAFS 法

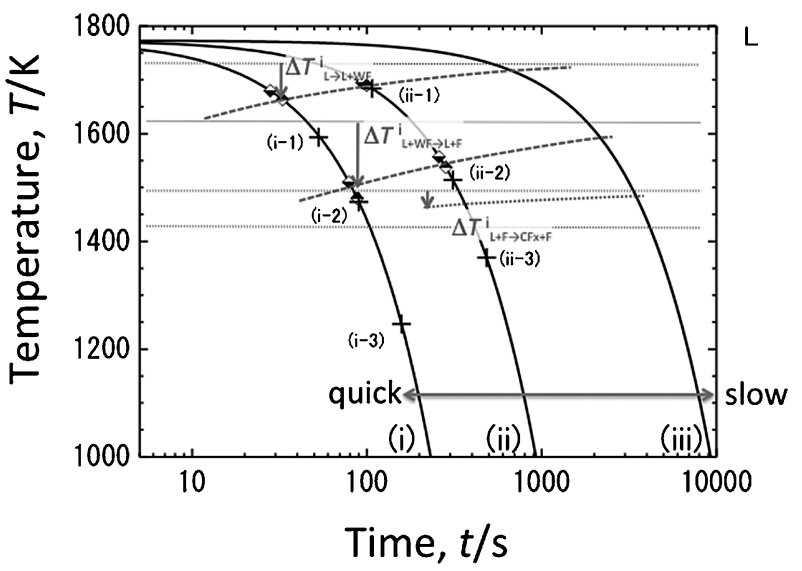

Fig. 5. First continuous cooling transformation (CCT) diagram for sintering of specimen Fe80Ca20. Solid lines show the time-temperature curves for cooling rates: (i) $-3.3 \mathrm{~K} / \mathrm{s}$, (ii) $8.3 \times 10^{-1} \mathrm{~K} / \mathrm{s}$, and (iii) $-8.3 \times 10^{-2} \mathrm{~K} / \mathrm{s}$. Dotted lines show the temperatures of phase transformation at equilibrium: $\mathrm{L} \rightarrow \mathrm{L}+\mathrm{M}, \mathrm{L}+\mathrm{M} \rightarrow \mathrm{L}+\mathrm{H}, \mathrm{L}+$ $\mathrm{H} \rightarrow \mathrm{CF}_{2}+\mathrm{H}$, and $\mathrm{CF}_{2}+\mathrm{H} \rightarrow \mathrm{CF}+\mathrm{H} . \Delta T_{\mathrm{X}}^{\mathrm{Y}}$ denotes the over-cooling temperature of the reaction $\mathrm{X}$ when cooled down with a rate of $\mathrm{Y}$ $(=\mathrm{i}, \mathrm{ii}$, or iii). Broken lines show those under non-equilibrium cooling conditions determined in this study. Boundaries determined by in situ Q-XRD and laser microscopy are shown by closed circles and diamonds, respectively. Typical conditions for industrial sintering processes are shown by the hatching area.
(X-ray absorption Fine Structure)を中心として測定を実 施した。

(b) MRO (Middle Range Order)

数十個の原子相関に対応する中距離範囲 $(1 \mathrm{~nm}<\lambda<$ 数 $10 \mathrm{~nm}$ 程度) まで，原子相関が確認できる原子の配列状態。

AXS 法 (Anomalous X-ray Scattering)により原子間の二 体相関を求め, モンテカルロ計算により構造を決定した。

(c) LRO (Long Range Order)

数百個レベルの多数の原子相関に対応する長距離範囲 $(100 \mathrm{~nm}<\lambda)$ まで，原子相関が確認できる原子の配列状 態。所謂, 結晶性の高い状態。

反応のナノレベルでの構造変化の結果から, 大気腐食に 伴うさびの生成反応を模式的に示すと Figure 6 のように なる。大気腐食反応の Stage I が，湿潤環境で溶出した金 属イオンが $\mathrm{Fe}(\mathrm{OH})_{\mathrm{x}}$ そしてさびの核 $(\gamma-\mathrm{FeOOH})$ を形成し ていく過程である(核生成過程 : nucleation process)。次の Stage II が，さびの核が成長し微粒子(サイズ : 1 nm)を 形成していく過程である(成長過程 : growth process)。こ うして形成された微粒子は, 湿潤↔乾燥サイクルの中で付 着・凝集・熟成等の変化を経てさび層（サイズ：数 $\mathrm{nm}$ ～ $100 \mu \mathrm{m})$ を形成する (Stage III)。このように, 大気腐食の 進行の各 Stage I III について, 大気中での耐食性を向上 させるための研究をおこなった。（木村ら，2002; Kimura et al., 2003, 2005, 2006)。

従来の鋼の腐食の場合では，さびの形成過程の反応速度 が比較的大きく核生成(析出)過程が律速になる(Fig. 6c)。 つまり，反応(腐食)速度が大きいため，生成した核はその

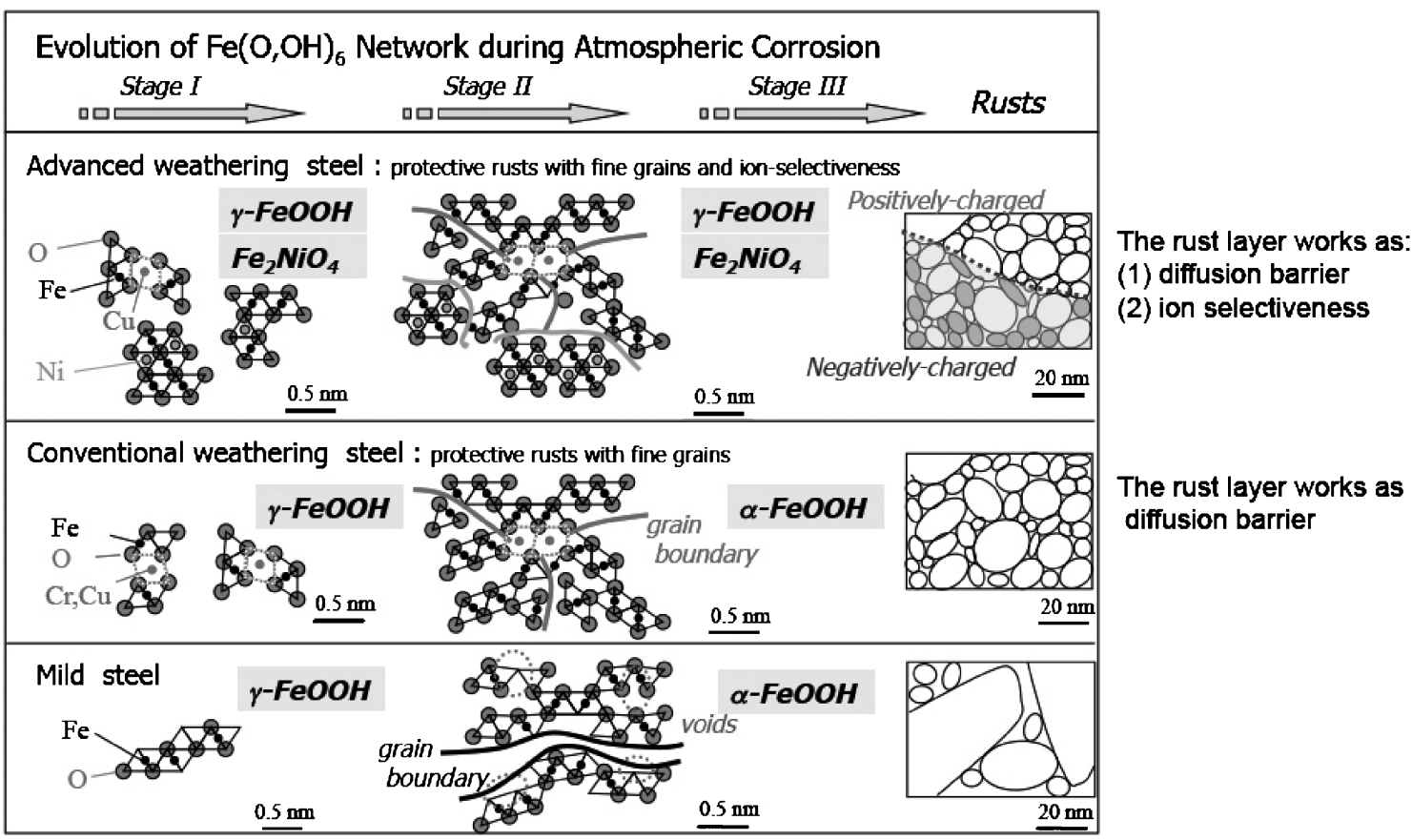

Fig. 6. Illustration of change in crystal structures during the sintering reaction in $\mathrm{CaO}-\mathrm{Fe}_{2} \mathrm{O}_{3}-\mathrm{SiO}_{2}-\mathrm{Al}_{2} \mathrm{O}_{3}$ system. 
まま大きな結晶粒へと成長する。その早い成長速度のた め, さびの ' $\mathrm{Fe}(\mathrm{O}, \mathrm{OH})_{6}$ Network' の $\mathrm{MRO}$ は低く, 欠陥 を多く含んだものになる。その結果, 最終的に得られるさ びは緻密性の低いものとなり, さらに腐食反応が進行して いく。それに対して，耐候性鋼では，さびの形成過程の反 応速度が比較的小さい，つまり粒成長過程が律速になる (Fig. 6b)。これは, 耐候性鋼では, $\mathrm{X}=\mathrm{Cr}, \mathrm{Cu}$ 等の元素 の添加が，（a）不均一点として核生成サイトを増加させ， さらに，(b) $\mathrm{X}(\mathrm{O}, \mathrm{OH})_{6}$ ユニットの変調によりさび形成 の臨界半径が減少する, の二点で作用し，多くの核生成サ イトで微細な核生成が生じるからと考えられる。さらに添 加元素により ' $\mathrm{Fe}(\mathrm{O}, \mathrm{OH})_{6}$ Network' 自身の電気化学的ポ テンシャルも変化し反応 (腐食) 速度自身が小さくなり Networkの MRO は高くなる。その結果, 細な核が大きな 結晶粒へと成長することが阻害され，最終的にできるさび の結晶粒径はより微細となり, 緻密な保護性さびが形成す る。

さらに厳しい腐食環境である海岸に近い地域での耐候性 を向上させるためには，さび層の物理的な緻密性を向上さ せるだけでなく，化学的な防食機構を付与することが必要 になる。そのため新しいタイプの耐候性鋼 ( '3Ni 高耐候性 鋼’) が開発された (Kihira et al., 1999 ; 紀平ら，2000)。 $3 \mathrm{Ni}$ 高耐候性鋼のさび形成反応の特徵 (Fig. 6a) は, (I) ナ ノサイズの微細粒から構成される緻密な内層が形成され る，（II）内層に含まれる $\mathrm{Fe}_{2} \mathrm{NiO}_{4}$ が塩素と反発的な相互 作用を示す，という2つの因子重要であると考えられる (Kimura et al., 2003, 2005)。初期の Stage I の湿潤↔乾燥 のサイクルの過程で, $\mathrm{Fe}_{2} \mathrm{NiO}_{4}$ という新たな相が形成さ れ，これが後の StageII, III にも残存し緻密なさび中にと りこまれる。コロイドの電気泳動法による測定を実施した ところ，湿潤環境において，通常のさび $(\alpha-\mathrm{FeOOH})$ は溶 液中の $\mathrm{H}^{+}$と結合して正電荷を帯びるのに対して, $\mathrm{Fe}_{2} \mathrm{NiO}_{4}$ は負電荷を帯びることが確認された。つまり塩分 を含む海水を含む水溶液によって濡れた際, 従来の材料で は表面に形成されるさびが正電荷を帯びて塩化物イオン
$\left(\mathrm{Cl}^{-}\right)$を引き寄せてさびに取り込まれる。そのため，表面 付近の $\mathrm{pH}$ が低下し, 腐食が進行し, さらにさびが形成す るという悪循環で腐食が進行した。それに対して，新型の $3 \mathrm{Ni}$ 高耐候性鋼では表面に形成されるさびが負電荷を帯び てナトリウムイオン $\left(\mathrm{Na}^{+}\right)$を引き寄せる。そのため, $\mathrm{pH}$ の低下が少なく，腐食が抑制されたと考えられる。

つまり，さびをもってさびを制するメカニズムは，水溶 液/酸化物の界面での反応がキーとなっていたのである。 これを明らかにするために，上述した様々なスケールでの 解析法を用いたが，それを概念的に示すと，（a）界面を串 刺しにして水溶液中の化学種を観察するアプローチと,

（b）水溶液を通して下側の固体界面を観察するアプロー チ，の両方から取り組んだことになる(Fig. 7)。こうした アプローチは，もちろん，腐食だけでなく，電池や水溶液 合成反応等, 様々な反応観察に展開できると考えている。

\section{IV.おわりに}

本稿では，鉄鋼プロセスの最上流である「鉄鉱石の液相 焼結」と材料として使われる最下流の「鋼の腐食」につい て，反応のキーとなる鉱物の原子構造単位の変化を「その 場 (in situ) and 動的 (dynamic) 観察」するためのオリジナ ルな観察法を開発し，それを適用することにより，プロセ スや材料活用の指針につながる知見を得られることを紹介 した。こうしたアプローチが有効となった事例は他にも沢 山あるのは言うまでもない。例えば, 酸化物超伝導体の研 究開発において, 同化合物のペロブスカイト型構造という 特徵を活かして，部分融体からの急冷と結晶成長核からの 結晶成長熱処理を組み合わせた新たなバルク材料作製プロ セス $\left(\mathrm{QMG}^{\circledR}:\right.$ Quench \& Melt Growth)の開発(Kimura et $a l ., 1991)$ においては，cm オーダーの材料を構成するぺロ ブスカイト相がぞのような方位関係で分布しているかを非 破壊 ·迅速 ·高精度で評価する観察法が材料プロセスの高 度化に大きく寄与した。また，ペロブスカイト酸化物系 $(\mathrm{Pd} / \mathrm{Sr}-\mathrm{Fe}-\mathrm{O})$ の排ガス浄化触媒の開発においては, “高温 でガス䨌囲気が短時間で変化する redox サイクルの中で,
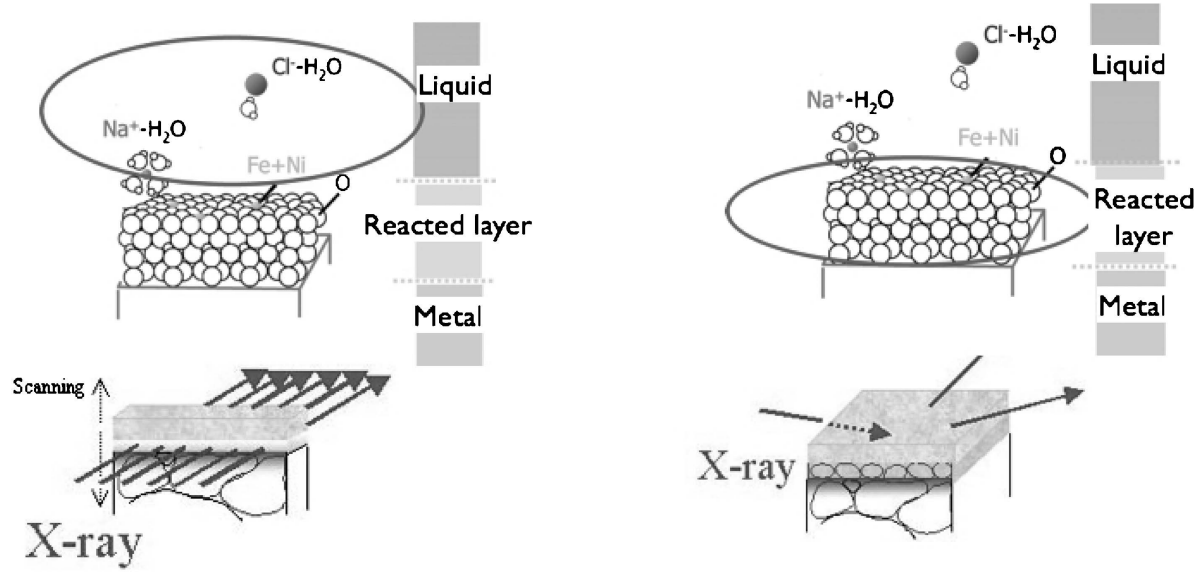

Fig. 7. Illustration of two-types of approach to investigate liquid/solid interface. 
酸化物の酸素欠陥と置換貴金属元素の価数摇動变化を数 $10 \mathrm{~ms}$ の時間分解能でその場観察する方法”を実現化する ことにより，排ガス浄化用の三元触媒(酸化還元触媒)に必 須とされている担持貴金属 $(\mathrm{Pd}, \mathrm{Pt}$ 抢よび $\mathrm{Rh}$ )の量を $70 \%$ 以上削減して同等の特性を有する触媒のメカニズム解明に 成功した (Kimura et al., 2013)。

反応のキーとなる鉱物の原子構造単位の変化を「その場 (in situ) and 動的 (dynamic) 観察」することが，プロセス や材料の研究開発に直結し, 結果として社会基盤インフラ や省元素・省エネルギーに寄与することに展開していくこ とを本稿にて実感して頂けたら幸いである。

謝 辞 本稿で紹介した研究は，新日本製鐵侏）[2013 年 10 月より，新日鐵住金(侏] での多くの方々との共同研 究の結果行われました。また実験を遂行するにあたり, 日 鉄住金テクノロジー侏にご協力頂きました。また放射光を 利用した研究は, 同社と高エネルギー加速器研究機構・物 質構造科学研究所との長年の共同研究により実現したもの であり，同研究所の多くの方々の支援を受けました。

高工ネ研は大学共同利用機関として多くの産官学の研究 者が集い実験をしており，そこでの出会いや協力関係が，

新たな研究のヒントとなったことも多々ありました。紙面 をお借りして，お世話になったすべての方々に厚く御礼申 し上げます。

最後になりましたが，日本鉱物科学応用鉱物科学賞を頂 いたこと心より感謝申し上げます。これを励久に，鉱物学 的視点を大切にして，今後も様々な反応系の研究に取り組 んでいきたいと考えております。今後も関係各位のご指導 ご指導・ご鞭撻を宜しくお願い申しあげます。

\section{引用文献}

Cornell, R.M. and Schwertmann, U. (2003): The Iron Oxides. Weinheim, Wiley-VCH Verlag GmbH \& Co. KGaA.

稲角忠弘 (2000)：焼結鉱一資源少国日本の挑戦記録一。東京，日 本鉄鋼協会.

紀平 寛, 伊藤 颚, 溝口 茂, 村田朋美, 宇佐見明, 田辺康児 （2000）：海浜耐候性鋼の成分設計コンセプト創出．材料と環
境, 49, 30-40.

Kihira, H., Usami, A., Tanabe, K., Ito, M., Shigesato, G., Tomita, Y., Kusunoki, T., Tsuzuki, T., Ito, S. and Murata, T. (1999): Development of wathering steel for coastal atmosphere. Electrochemical Soc. Int. Symp., Honolulu, The Electrochemical Soc.

Kimura, M., Kihira, H., Ishii, Y. and Mizoguchi, T. (2003): Corrosion protection mechanism of $3 \% \mathrm{Ni}$ weathering steel. 13th Asian-Pacific Corrosion Control Conference, Osaka.

Kimura, M., Kihira, H., Ohta, N., Hashimoto, M. and Senuma, T. (2005): Control of $\mathrm{Fe}(\mathrm{O}, \mathrm{OH})_{6}$ nano-network structures of rust for high atmospheric-corrosion resistance. Corros. Sci. 47, 2499-2509.

Kimura, M., Mizoguchi, T., Kihira, H. and Kaneko, M. (2006): Various scale Analyses to Create Functioning Corrosion Products. In Characterization of Corrosion Products on Steel Surfaces (Waseda, Y. and Suzuki, S. Eds.). Berlin, Springer, 245-272.

Kimura, M. and Murao, R. (2013): "Continuous cooling transformation (CCT)" concept for iron ore sintering using in situ quick $\mathrm{X}$-ray diffraction and confocal laser microscope. ISIJ International, 53, 2047-2055.

Kimura, M., Niwa, Y., Uemura, K., Nagai, T., Inada, Y. and Nomura, M. (2013): In situ and simultaneous observation of Palladium Redox and Oxygen Storage/Release in $\mathrm{Pd} / \mathrm{Sr}-\mathrm{Fe}-\mathrm{O}$ Perovskite Catalysts using Dispersive XAFS. Materials Transactions, 54, 246-254.

木村正雄, 鈴木環輝, 重里元一, 齋藤正敏, 鈴木 茂, 紀平 寛, 田辺康児, 早稲田嘉夫 (2002) : 耐候性鋼に形成されるさ びの $\mathrm{Fe}(\mathrm{O}, \mathrm{OH})_{6}$ ネットワーク構造. 日本金属学会誌, 66, 166-175.

Kimura, M., Tanaka, M., Horiuchi, H., Morita, M., Matsuo, M., Morikawa, H. and Sawano, K. (1991): A New Domain Structure in $\mathrm{YBa}_{2} \mathrm{Cu}_{3} \mathrm{O}_{7-\mathrm{x}}$ Prepared by the Quench and Melt Growth (QMG) Process. Physica C, 174, 263-272.

清川昌一(2000) : 太古代の世界一ピルバラクラトンからのメッ セージー. 地学雑, 109, 130-139.

Larabee, C.B. and Coburn, S.K. (1962): The Atmospheric Corrosion of Steels as Influenced by Changes in Chemical Composition [Corten (U.S. Steel)]. Int. Congress on Metallic Corrosion, London, U.K.

Matsushima, I. (1995). Low-Alloy Corrosion Resistant Steel, Chijin Shokan.

Misawa, T., Asami, K., Hashimoto, K. and Shimodaira, S. (1974): Mechanism of atmospheric rusting and the protective amorphous rust on low alloy steel. Corros. Sci. 14, 279-289. 